tosynthetic genes in Cucumis sativus Planta 230: 1185-1196-1196.

Yamauchi, A., A. Hosokawa, H. Nagata and M. Shimoda (2004): Triploid bridge and role of parthenogenesis in the evolution of autopolyploidy. Am Nat 164: 101-112.

ZHANG, Q., Z. Y. ZHANG, S. Z. LIN and Y. Z. LIN (2005): Resistance of transgenic hybrid triplolds in Populus tomentosa Carr. against 3 species of lepidopterans following two winter dormancies conferred by high level expression of cowpea trypsin inhibitor gene. Silvae Genetica 54: 108-116.
Zhang, Q., Z. Y. Zhang, S. Z. LiN, H. Q. Zheng, Y. Z. LiN, X. M. AN, Y. LI and H. X. Li (2008): Characterization of resistance gene analogs with a nucleotide binding site isolated from a triploid white poplar. Plant Biol (Stuttg) 10: $310-322$.

Zheng, H., S. Lin, Q. ZhANG, Y. LeI and Z. ZHANG (2009): Functional analysis of 5' untranslated region of a TIRNBS-encoding gene from triploid white poplar. Mol Genet Genomics 282: 381-394.

\title{
Reconstructing explicit mating schemes in poplar hybrids - a case study in the Populus nigra L. - Populus $\times$ canadensis Moench complex
}

\author{
By R. Bialozyt ${ }^{1), *)}$, G. RathmacheR ${ }^{1)}$, M. NiggemanN ${ }^{1)}$ and B. Ziegenhagen ${ }^{1)}$
}

(Received $17^{\text {th }}$ November 2011)

\begin{abstract}
In the plant kingdom, a large percentage of taxa are known to interbreed. If these hybrids are fertile, introgressive gene flow may foster the development of hybrid swarms or even promote gene swamping. Our study focuses on the Eurasian black poplar (Populus nigra L.) which may be threatened by hybridization with the cultivated fertile Euramerican hybrid. Using a combination of taxa specific DNA markers from the chloroplast and the nuclear genome we set up a straightforward and cost efficient method for identification of all possible mating scenarios in the hybrid complex of $P$. nigra and its cultivar Populus $\times$ canadensis Moench. Within a mixed population, we analyzed seed collections from individual trees of both taxa as well as juveniles from natural regeneration for proportions of second-generation hybrids (F2 hybrids) and first generation backcrosses. While F2 hybrids were detected in the seeds only, first generation backcrosses occurred in seeds as well as in juveniles. Due to the meiotic segregation of alleles, a certain amount of such progeny may remain undetected. Based on Mendelian rules, we developed a scheme to adjust the observed proportion of hybrid progeny for these undetected cases. Moreover, the scheme can be used to iteratively add loci necessary to detect poplar hybrids beyond the second hybrid and first generation backcrosses. We questioned whether there is a risk of hybrid swarm formation or swamping of the $P$. nigra gene pool. We discuss the likelihood of such a scenario and draw conclusions for conservation issues while poplar plantations are increasingly appreciated as renewable resources.
\end{abstract}

1) Philipps-University of Marburg, Faculty of Biology, Conservation Biology, Karl-von-Frisch-Strasse 8, D-35032 Marburg, Germany.

*) Corresponding author: RonAld BialozYT.

Tel.: +49-6421-2824878; Fax: +49-6421-2826588

E-Mail: bialozyt@biologie.uni-marburg.de
Key words: introgression, gene flow, hybrid swarm, SSR, $P . \times$ canadensis, diagnostic DNA markers, short rotation plantation.

\section{Introduction}

Hybridization is one of the prominent drivers of diversification and speciation, particularly in plants (ARNOLD, 1997; MALLET, 2005), and is therefore a topic of interest in plant evolutionary biology. Hybridization followed by introgression turns into an issue of invasion biology when the species involved are naturally separated geographically, but have been brought together by man (ElTon, 1958; RichARDson et al., 2000; MOONEY and CleLAND, 2001). Introgressive gene flow from the exotic species may drive the native species into extinction, given that the latter is a relic and the gene pool is therefore susceptible to being swamped by the foreign genes (Rhymer and Simberloff, 1996; Mooney and Cleland, 2001). Such a case of 'genomic invasion' (MALLET, 2005; KELLER and TAYLOR, 2010) may be relevant in the genus Populus, where fast-growing hybrids have been produced from artificial crosses between various species from different continents.

European $P$. nigra populations have long been threatened by various factors, such as river regulation, followed by habitat destruction and replacement by pastures or hardwood forest (LEFÈvRE et al., 1998, 2001; TABBENER and CotTrell, 2003; Pospísková and SÁLKOVÁ, 2006). Furthermore, a tremendous amount of hybrid poplar plantations emerged in the landscape after tree breeders artificially produced first generation hybrids (F1) of poplar species in the middle of the $19^{\text {th }}$ century. Fast growing F1 hybrids Populus $\times$ canadensis Moench have been obtained from crosses of the North American Populus deltoides Bartr. with the Eurasian black poplar Populus nigra L. (Melchior and SEITZ, 
1968; ZSUFFA et al., 1999). Since these hybrids are fertile and massively cultivated in close vicinity to relic native Eurasian $P$. nigra, they are principally able to generate second generation hybrids (F2) and first generation backcrosses, respectively (BRADSHAW et al., 2000; VANDEN BROECK et al., 2003a). While field studies revealed some preliminary evidence for the presence of introgressed poplars using molecular markers (CAGELLI and LEFÈVRE, 1995; VANDEN BROECK et al., 2004; PosPísKovÁ and SÁlková, 2006; SMulders et al., 2008; Ziegenhagen et al., 2008; CsEnCsics et al., 2009), refined tools and analyses that avoid the misclassification of progeny are still missing. Available software packages like Structure (PRITCHARD et al., 2000) or NewHybrid (ANDERSON and THOMPSON, 2002), which are often used in such investigations (MEIRMANs et al., 2007; SMULDERs et al., 2008; KELLER et al., 2010; THOMPSON et al., 2010), fail to give correct classification, if only one parental species is available, as in our case. Here, only $P$. nigra and its hybrid are interacting within the landscape. Furthermore, these software packages are based on the assumptions of Hardy-Weinberg-equilibria (HWE), which are hard to argue in cases where the existence of reproductive barriers cannot be excluded. A best possible procedure and effective risk management, however, relies on diagnostic methods that assure correct classification and the best possible quantification of hybrid progeny.
The present study attempts to identify and quantify second generation hybrids (F2) and first generation backcrosses (BC 1) in subsets of progeny, which originate from a relic black poplar population interspersed with $P$. $\times$ canadensis trees. It uses a combination of species diagnostic markers for $P$. deltoides from the nuclear and the chloroplast genome. As revealed in other studies (HEINZE and LICKL, 2002; HEINZE, 2008; ZiEGENHAGEN et al., 2008; CsENCSICS et al., 2009), such a combined marker approach is highly promising. The maternally inherited chloroplast marker DT (DEMESURE et al., 1995) is useful for unambiguously identifying all $P . \times$ canadensis commercial $\mathrm{F} 1$ hybrids since they all carry the $P$. deltoides haplotype. Hence, the chloroplast marker identifies hybrids of the second or further generations that have descended from the maternal $P$. deltoides lineage. Combined with the information from nuclear loci it should be possible to detect the presence of backcrosses or F2 hybrids (HEINZE, 1998). Due to Mendelian segregation of the species diagnostic nuclear alleles, however, a proportion of such matings will remain undetected and this may lead to underestimation of the risk of invasive gene flow. For this reason, we have increased the number of nuclear loci from just one diagnostic biallelic nuclear marker locus used in the previous study (ZIEGENHAGEN et al., 2008) to four microsatellite loci, each carrying a diagnostic allele for

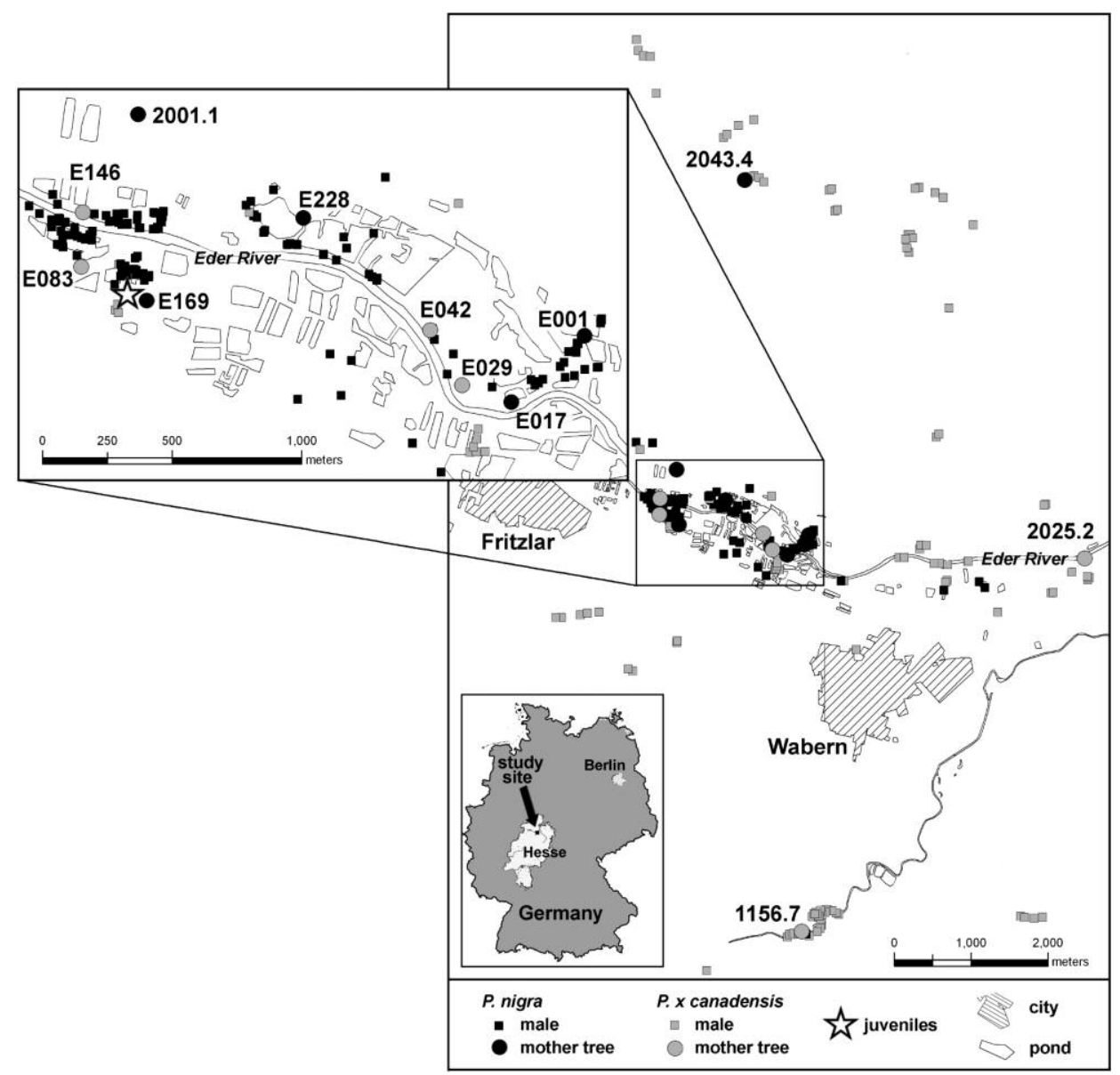

Figure 1. - Distribution of sampled mother and male poplar trees at the study site. A large star indicates the location of juvenile progeny. Sample names of sampled mother trees are indicated. Species affiliation corresponds to RATHMACHER et al. (2010). 
$P$. deltoides. In addition, we created a scheme based on Mendelian rules, which helps to quantify the detectable proportions of F2 hybrids and first generation backcrosses. We classified and quantified the hybrid background in a large amount of seeds, which were obtained from several single-tree progenies. Furthermore, juveniles that had naturally established in the study region were also analyzed. The results are discussed with regard to a potential risk of hybrid swarm formation and gene swamping. Conclusions are drawn for the usability of our scheme in conservation management of Populus nigra and for risk analysis of short rotation plantations.

\section{Material and Methods}

\section{Study site and plant material}

The study site is located in Hesse, Central Germany,

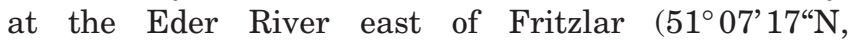
$9^{\circ} 18^{\prime} 45^{\prime \prime E}$, Fig. 1). It represents the conservation area "Ederauen bei Obermöllrich und Cappel", which includes a large natural $P$. nigra population. It consists of about 300 adult trees with a nearly balanced sex ratio. This population is interspersed with and surrounded by numerous trees of $P \times$ canadensis, which introduce an excess of males into the landscape due to a dominant male clone ("Robusta").
In two consecutive years (2006 and 2007), mature seeds were harvested directly from 12 mother trees, six from each taxa (Fig. 1, Table 1). A taxonomic classification of all adult trees including the mother trees was carried out in a previous study (RATHMACHER et al., 2010). Collected seeds were transferred to filter paper placed on waterlogged vermiculite. Three to four days after germination, the seedlings were collected and dried before DNA extraction.

Natural regeneration within the study site could only be found within one gravel-pit of approximately $100 \times 100 \mathrm{~m}^{2}$ in size (Figs. 1 and 2). We sampled leaves from 380 juvenile plants at an age of about two to six years. All samples were dried at $36^{\circ} \mathrm{C}$ for 24 hours. Approximately $0.5 \mathrm{~cm}^{2}$ of leaf area or the whole seedling respectively were homogenized, following the protocol by ZiEgenHAGEN et al. (1993). Total DNA was extracted according to JUMP et al. (2003) with slight modifications as described in RATHMACHER et al. (2009).

\section{Molecular analysis}

\section{Nuclear SSR markers}

The two subsets of progeny were analyzed at four highly polymorphic nSSR loci: WPMS09 (VAN DER Schоoт et al., 2000), WPMS18 (SMULDERs et al., 2001), PMGC14 and PMGC2163, which were selected from the

Table 1. - Quantity of diagnostic alleles at four SSR loci of seedlings from P. nigra mothers (a) and $P . \times$ canadensis mothers (b). The number of seedlings indicates the amount of seedlings that are either a backcrossed individual (a) or F2 hybrid (b). BC 1: backcross; F2: F1 hybrid $\times$ F1 hybrid; Corr: the corrected value according to the respective scheme (Fig. 3).

(a)

\begin{tabular}{|c|c|c|c|c|c|c|c|c|c|c|}
\hline \multirow{3}{*}{$\begin{array}{r}\text { Tree ID } \\
\text { Year } \\
\text { Sample } \\
\text { size }\end{array}$} & \multirow{2}{*}{$\begin{array}{r}2001.1 \\
2007\end{array}$} & \multirow{2}{*}{$\begin{array}{r}2043.4 \\
2007\end{array}$} & \multicolumn{2}{|c|}{ E001 } & \multicolumn{2}{|c|}{ E017 } & \multicolumn{2}{|c|}{ E169 } & \multicolumn{2}{|c|}{ E228 } \\
\hline & & & 2006 & 2007 & 2006 & 2007 & 2006 & 2007 & 2006 & 2007 \\
\hline & 190 & 95 & 95 & 136 & 105 & 191 & 136 & 191 & 51 & 190 \\
\hline WPMS 09 & & 34 & & & 1 & & & & & \\
\hline WPMS 18 & & 39 & & & & & & & & \\
\hline PMGC 14 & & 42 & 6 & 2 & & & & & & 1 \\
\hline $\begin{array}{r}\text { PMGC } \\
2163 \\
\end{array}$ & & 45 & & 2 & & & & & & 1 \\
\hline \# seedlings & & 74 & 6 & 4 & 1 & & & & & 2 \\
\hline BC 1 [\%] & & 77.89 & 6.32 & 2.94 & 0.95 & & & & & 1.05 \\
\hline Corr [\%] & & 83.08 & 6.74 & 3.14 & 1.01 & & & & & 1.12 \\
\hline
\end{tabular}

(b)

\begin{tabular}{|c|c|c|c|c|c|c|c|c|c|}
\hline \multirow{2}{*}{$\begin{array}{r}\text { Tree ID } \\
\text { Year } \\
\text { Sample }\end{array}$} & \multirow{2}{*}{$\begin{array}{r}1156.7 \\
2007\end{array}$} & \multirow{2}{*}{$\begin{array}{r}2025.2 \\
2007\end{array}$} & \multicolumn{2}{|c|}{ E029 } & \multirow{2}{*}{$\begin{array}{l}\text { E042 } \\
2006\end{array}$} & \multicolumn{2}{|c|}{ E083 } & \multicolumn{2}{|c|}{ E146 } \\
\hline & & & 2006 & 2007 & & 2006 & 2007 & 2006 & 2007 \\
\hline size & 190 & 190 & 173 & 146 & 89 & 96 & 194 & 53 & 95 \\
\hline WPMS 09 & 2 & 6 & 1 & & & & & & \\
\hline WPMS 18 & 1 & 3 & 2 & & & 1 & & & \\
\hline PMGC 14 & 1 & 3 & & & & 2 & 2 & & \\
\hline $\begin{array}{r}\text { PMGC } \\
2163 \\
\end{array}$ & & 7 & 1 & & 1 & & & & 1 \\
\hline \# seedlings & 2 & 12 & 4 & & 1 & 2 & 2 & & 1 \\
\hline F2 [\%] & 1.05 & 6.32 & 2.31 & & 1.12 & 2.08 & 1.03 & & 1.05 \\
\hline Corr [\%] & 1.54 & 9.25 & 3.38 & & 1.64 & 3.04 & 1.51 & & 1.54 \\
\hline
\end{tabular}




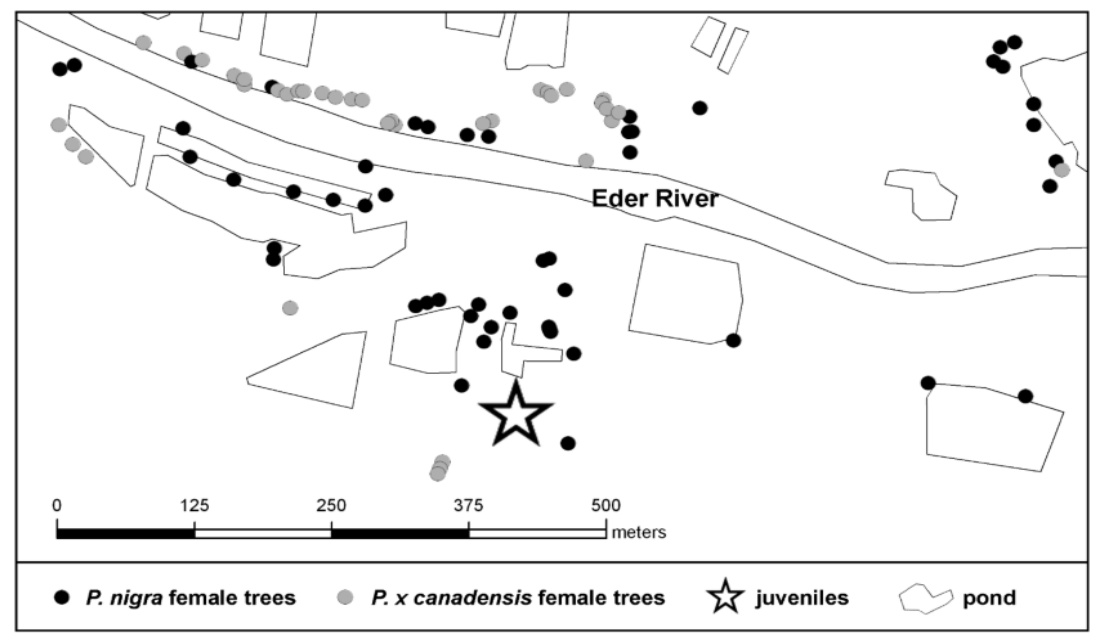

Figure 2. - Distribution of female poplar trees around the sampled juveniles in a gravel pit at the study site. For clarity, only the surrounding females are indicated. The species affiliation corresponds to RATHMACHER et al. (2010).

IPGC (International Populus Genome Consortium) SSR Resource. All markers are completely unlinked (CERvera et al., 2001; GAUDET et al., 2008) and possess species diagnostic alleles for P. deltoides (Fossati et al., 2003; BeKKAOUI et al., 2003; KHASA et al., 2005). PCR, automated multiplex capillary electrophoresis and genotyping were performed as described by RATHMACHER et al. (2009). In order to verify a correct SSR genotyping the genotypes of the mother trees had been compared with those of the seeds at all four loci. Those cases where the "mother allele" was not retrieved in the seeds contribute to the so-called mistyping error.

\section{Chloroplast DNA marker}

The chloroplast (cp) DNA marker DT (DEMESURE et al., 1995) was used to identify the maternal origin of the juveniles. The marker variation is characterized by a fragment length polymorphism in the intergenic spacer region between the $\operatorname{trn} D$ and $\operatorname{trnT}$ genes. At the DT region, $P$. nigra and $P$. deltoides are characterized by diagnostic alleles (HEINZE, 1998). Reference samples of pure $P$. nigra and $P$. deltoides as well as $P$. $\times$ canadensis (kindly provided from the poplar clone collection in Hannoversch Münden, Germany) were included as positive controls to assure the correct assignment of the diagnostic length variants to either $P$. nigra or $P$. deltoides maternal lineages (ZIEGENHAGEN et al., 2008; RATHMACHER et al., 2010). The total PCR volume of $16 \mu \mathrm{l}$ contained $1 \mu l$ of template DNA (10 $n g), 1 \times$ PCR reaction buffer, $2 \mathrm{mM} \mathrm{MgCl}, 0.2 \mu M$ of each primer, $0.2 \mathrm{mM}$ of each dNTP and $0.25 U$ of Taq-polymerase (Bioline USA Inc.). The PCR cycle started with an initial denaturation at $94^{\circ} \mathrm{C}$ for $4 \mathrm{~min}$ and was followed by 25 cycles of denaturation at $94^{\circ} \mathrm{C}$, annealing at $55^{\circ} \mathrm{C}$ and elongation at $72^{\circ} \mathrm{C}$ for $45 \mathrm{sec}$ each. The diagnostic variants were detected in simple $2 \%(0.5 \times \mathrm{TBE})$ agarose gels (ZIEGENHAGEN et al., 2008).

\section{Quantification scheme of hybrid progeny}

From the taxonomic status of the adult population we may expect hybrid progeny with the following parental combinations, i) $P$. nigra $\times \mathrm{F} 1$ hybrid $(P . \times$ canadensis $)$, ii) F1 hybrid $\times$ F1 hybrid, and iii) $\mathrm{F} 1$ hybrid $\times P$. nigra. Classification of the maternal taxa was simple. In the case of the single tree progeny, the taxon of the maternal parent had been unambiguously assessed by a previous molecular study (RATHMACHER et al., 2010). In the case of the juveniles, the maternal background was unraveled using the cp DNA marker. As soon as this marker displays the $P$. deltoides type, we can conclude that this offspring had an F1 hybrid as mother, case ii) and iii). In the other case, this offspring had a $P$. nigra as mother.

Classification and quantification of the paternal origin, however, is much more difficult due to Mendelian segregation of the nuclear diagnostic alleles. As all marker loci are transmitted independently (CERVERA et al., 2001; GAUDET et al., 2008), each parental allele is passed on to the offspring with a probability of $50 \%$. Therefore, in an extreme case, offspring may display no alleles that are diagnostic for $P$. deltoides at all four diagnostic nuclear marker loci, even in cases where both parents were $P$. $\times$ canadensis.

To overcome this shortcoming we developed a step-bystep scheme which accounts for segregation probabilities and is considering the case where we do not have ordered alleles. The three possible mating schemes are reduced to only two, in which the cases i) and iii) follow equivalent schemes due to the fact that we cannot discern between the maternal or paternal allele at the nuclear level and at most one diagnostic allele occurs at the marker loci (Fig. 3a). This is different from case ii) where an F2 offspring is unambiguously classified when the $P$. deltoides diagnostic allele occurs in a homozygous status (Fig. 3b).

In all cases, our calculations start with the observed proportions. Next, segregation probabilities are used to determine the 'detectable' proportion (Figs. $3 a$ and $3 b$ ). Finally, a 'corrected' value is obtained from the observed proportion using the 'Rule of Three' cross-multiplication.

In case i), the occurrence of any diagnostic allele for $P$. deltoides in $P$. nigra maternal offspring indicates 

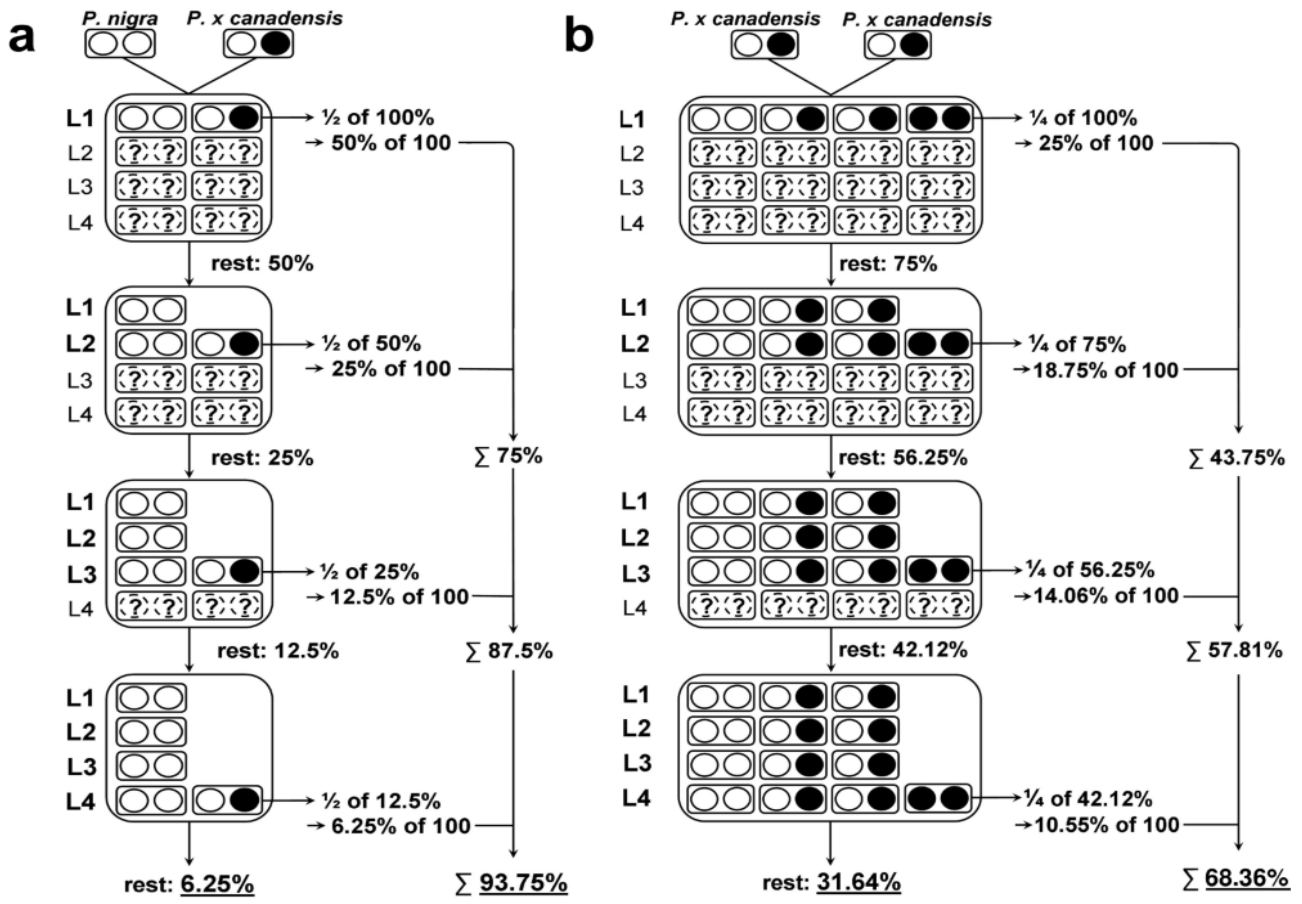

Figure 3. - Illustration of the two possible mating schemes (see text for details) used to cumulatively calculate the detectable proportion of first generation backcrosses (a) and F2 progeny (b). Each rectangular box represents one possible allele combination of the respective mating at the four marker loci (L1-L4) according to Mendelian rules. Each of the four loci may harbor a diagnostic allele for $P$. deltoides. These are marked by filled circles. In scheme (a) detection of a hybrid parenthood is possible by identification of one diagnostic marker, whereas in scheme (b) unambiguous detection of a hybrid paternity is realized detecting a homozygous locus.

P. $\times$ canadensis paternity. Using just one diagnostic marker, only half of the offspring from such matings will display the diagnostic allele for $P$. deltoides and therefore be assigned to a backcrossed individual (Fig. 3a). Thus, the detectable proportion of backcrossed individuals can be calculated as

$$
\begin{aligned}
& P(1)=1-(1-a) \\
& P(1)=a
\end{aligned}
$$

where ' $P(1)$ ' denotes the detectable proportion if only one locus is used and ' $a$ ' describes the probability that the diagnostic marker is transferred to the offspring.

Using a second diagnostic marker locus, another fraction of $50 \%$ of the remaining unassigned offspring can be identified as backcrosses, which adds a proportion of $25 \%$ to the detectable backcrosses. Considering a third and fourth diagnostic marker, additional proportions of $12.5 \%$ and $6.25 \%$ can be assigned, respectively. Therefore one might extend equation (1) to

$$
P(4)=1-\left(1-a_{1}\right) \cdot\left(1-a_{2}\right) \cdot\left(1-a_{3}\right) \cdot\left(1-a_{4}\right)
$$

where ' $P(4)$ ' denotes the detectable proportion if four loci are used and ' $a$ ' describes the probability of the locus ' $i$ ' that the diagnostic marker is transferred to the offspring. In our case, where all loci display the same probabilities equation (2) may be simplified to

$$
P(b)=1-(1-a)^{b}
$$

where ' $P(b)$ ' denotes the detectable proportion using ' $b$ ' number of loci and ' $a$ ' is the common probability of all loci. The application of equation (3) and a detection probability of 0.5 for each locus results in a total of $93.75 \%$ of the offspring that have an $\mathrm{F} 1$ hybrid poplar as father. Still, a proportion of $6.25 \%$ will remain undetected.

In order to obtain the corrected value of backcross proportions, we therefore used the simple 'Rule of Three' cross-multiplication:

$$
d=\frac{c \cdot 100}{a}
$$

with $d$ = 'corrected proportion' of backcrossed offspring, $c=$ number of observed backcrossed progeny using four diagnostic markers, and $a=$ detectable fraction of backcrossed progeny. In our case i) 'a' equals $93.75 \%$. The remaining seedlings were classified as pure $P$. nigra offspring (Fig. 3a). The scheme for case iii) would be analogous and would provide the same cumulative probabilities.

The procedure for case ii) is similar in principle but comes up with different probabilities for detecting a hybrid father. Progeny that are homozygous for at least one diagnostic allele for $P$. deltoides can be unambiguously classified as F2 hybrids, thus having an F1 hybrid as father. To calculate the cumulative proportion for four diagnostic marker loci, we followed the scheme for cases i) and iii) explained above. In all steps of this procedure, only $25 \%$ of the resulting offspring would possess a locus homozygous for the diagnostic allele for $P$. deltoides. Using the four diagnostic marker loci, $68.36 \%$ of 
the offspring that actually are F2 hybrids can be detected, while $31.64 \%$ would still remain undetected (Fig. $3 b)$. In order to estimate the corrected values of F2 hybrids we again used equation (4).

\section{Projections}

Our scheme lends itself for two projections. The first projection is meant to learn about the detectable proportions of progeny displaying a hybrid background in consecutive generations using our marker system of four diagnostic loci. We constructed this projection on the simple assumption that a 'pure' $P$. nigra individual mates with one hybrid individual originating from the former backcross generation (BC 1-7). Since all four loci are inherited independently, we start with calculating the probability of detecting the diagnostic allele in consecutive backcross generations (BC 1-7) for a single locus. For each such mating this is the probability of transmitting the diagnostic allele to the next generation times the proportion of this allele in the current backcross generation. In a diploid organism, the iterative calculation allows for a simplification with the detection probability of the relevant hybrid equaling the trans mission probability to the power of the number of backcross generations $(g)$. This detection probability can be easily extended to all four loci by introducing $(g)$ into equation (3):

$$
P(b)=1-\left(1-a^{g}\right)^{b}
$$

The second projection is meant to estimate the amount of diagnostic marker loci needed to detect repeated backcrosses in subsequent generations with sufficient probabilities. Equation (5) can be used to calculate these values for each backcross generation $(g)$ and for a varying the amount of loci $(b)$ selected.

\section{Results}

From a total of 3000 sown seeds, 2606 seedlings were harvested and used for molecular analysis. The germination rate was high $(87 \%)$ and did not differ significantly between single tree progeny or taxa, respectively. Approximately $98 \%$ of the alleles of the four loci could be successfully identified. The mistyping rate of microsatellite genotypes was as low as 0.0456 (RATHMACHER et al., 2010).

\section{Seedlings of P. nigra mothers}

The observed proportions of seeds from $P$. nigra mother trees that originated from pollination by P. $\times$ canadensis pollen ranged from $0 \%$ to $77.9 \%$, with a mean of $8.9 \%$ (Table 1). In the one extreme case, however, with $77.9 \%$ backcrossed seedlings, the tree concerned (2043.4) is located far outside the main P. nigra population. The corrected proportion was not substantially different from the detected. Only for this particular tree (2043.4), was there a notable deviation of 4.3 from $77.9 \%$ to $83.2 \%$. All other seedlings are presumed to be descendants of $P$. nigra fathers.

\section{Seedlings of $P . \times$ canadensis mothers}

The mean proportion of F2 hybrids among the seedlings of $P . \times$ canadensis mothers was $1.67 \%$, the variation of this proportion among trees being less skewed than in the case of $P$. nigra mother trees (Table 1). F2 hybrids were found in seedlings of all mother trees except for E029 in 2007 and E146 in 2006. While the proportion of detectable F2 hybrids was low, at $68.36 \%$ (Fig. 3b), the corrected value pointed to a higher possible proportion (Table 1). Most seeds originated from pollinations by $P$. nigra, even in cases where

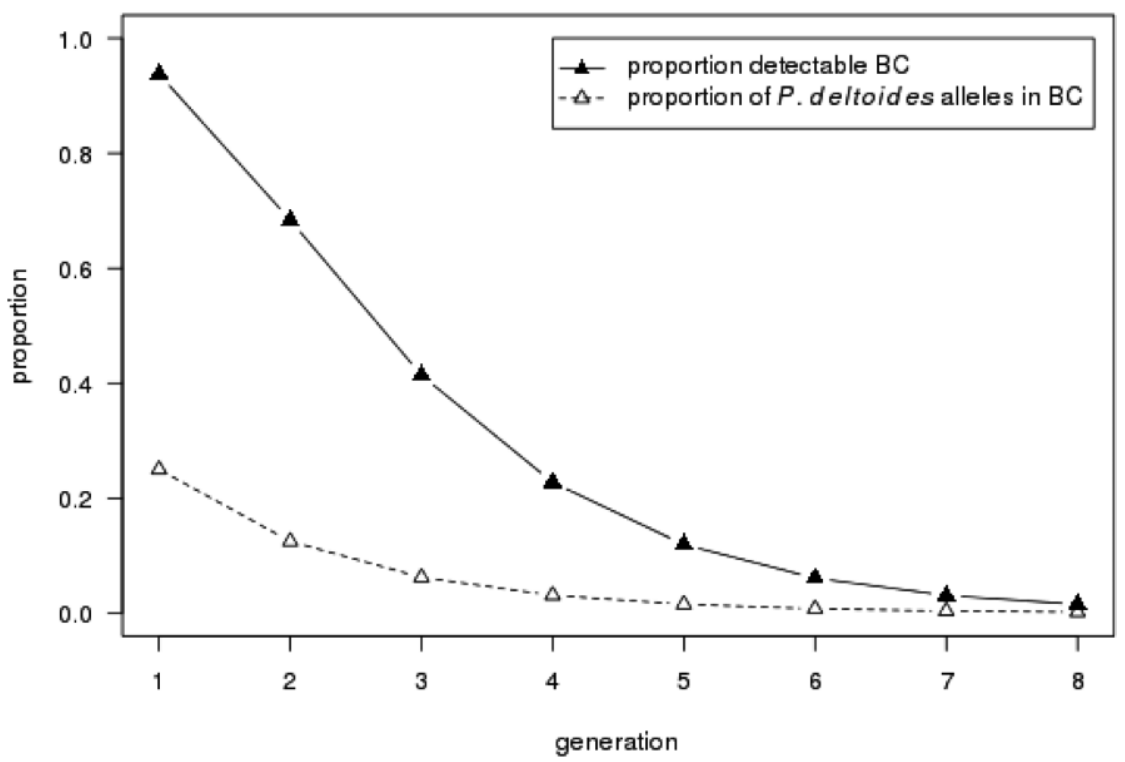

Figure 4. - Proportions of detectable backcrosses (filled triangles) and corresponding proportions of $P$. deltoides genes (open triangles) over eight consecutive generations using four diagnostic marker loci. In the first generation, mating took place between $P$. nigra and $P$. $\times$ canadensis individuals to produce first backcross generation (BC 1). The subsequent generations are the result of repeated backcrosses of an individual of the previous backcrossed generation (BC 1-BC 7) with pure P. nigra. 


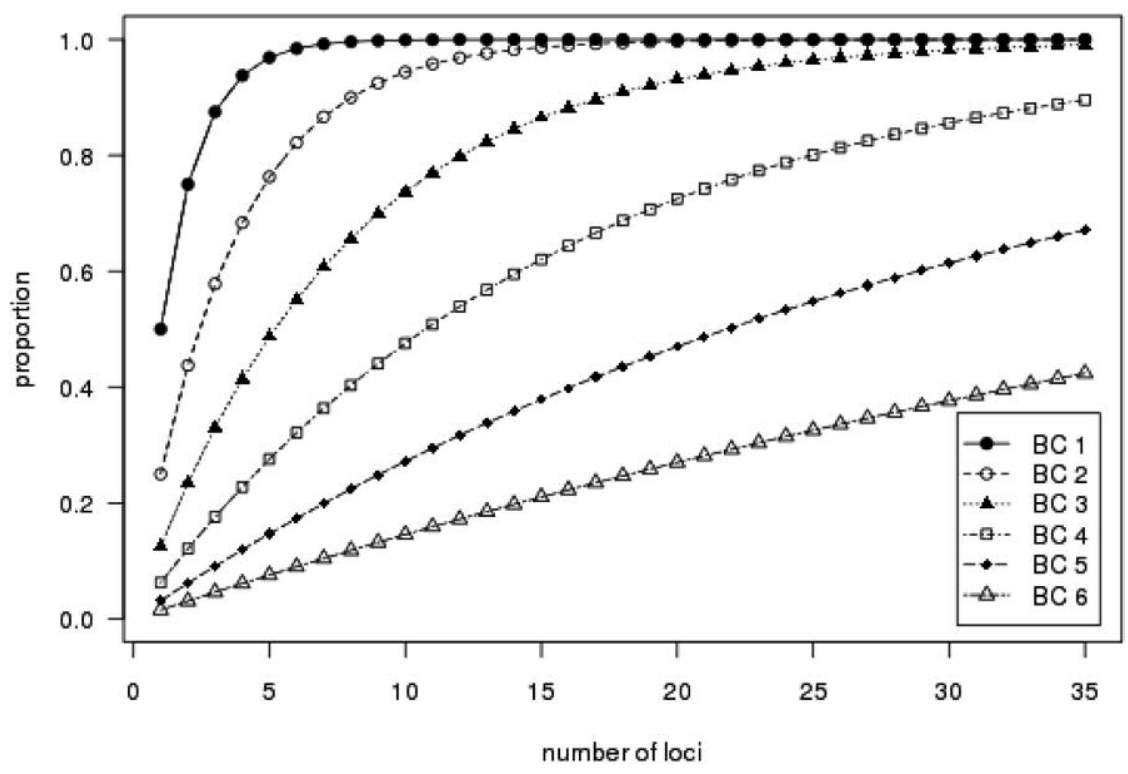

Figure 5. - Proportions of individuals with $P . \times$ canadensis ancestry in subsequent backcrossed generations that can be detected by adding more diagnostic nuclear marker loci. The first generation backcross (BC 1) is the result of mating between $P$. nigra and $P . \times$ canadensis individuals. The subsequent generations are the result of mating of an individual from the previous backcross generations and pure P. nigra. BC 1-BC 6: backcrossed generations 1-6.

only a few $P$. nigra males were in close vicinity, as is the case for tree 1156.7 and 2025.2 .

\section{Naturally regenerated juveniles}

From a total of 380 juvenile poplars, 372 individuals originated from a $P$. nigra mother, whereas eight juvenile trees $(2.1 \%)$ could be assigned to $P$. $\times$ canadensis maternal origin. One of these did not harbor any diagnostic nuclear allele for $P$. deltoides at all, while the other seven samples exhibited one to three alleles diagnostic for $P$. deltoides in the nucleus. Out of the 372 juveniles with $P$. nigra as mother, $P . \times$ canadensis paternity was detected in seven samples $(1.9 \%)$. All of these samples possessed the diagnostic allele for $P$. deltoides at just one of the four nuclear loci. After correction for the undetectable cases, the proportion of backcrosses with $P$. $\times$ canadensis amounted to $2.2 \%$.

With regard to all 380 sampled juveniles, the detectable fraction of individuals exhibiting $P$. $\times$ canadensis parentage (15 individuals, $4.0 \%)$ was corrected to 16 individuals $(4.2 \%)$. Half of these are characterized by $P . \times$ canadensis and the other half by $P$. nigra maternity. No F2 hybrids could be unambiguously identified within the subset of established juveniles, as diagnostic alleles for $P$. deltoides did not occur in a homozygous state. However, from the eight juveniles displaying a maternal "deltoides" background we calculated a possible proportion of $31.64 \%$ or 2.5 individuals which could be in fact true F2 hybrids.

\section{Projections}

In repeated backcrosses, the proportion of $P$. deltoides alleles halves from generation to generation. In generation ' 1 ' there are still $25 \%$ of the alleles originating from $P$. deltoides. In generation ' 2 ' this value decreases to
$12.5 \%$ and in generation ' 8 ' the proportion of $P$. deltoides alleles becomes as low as $0.2 \%$ (Fig. 4).

The projection of detectable proportion of backcrosses follows a different rule. Based on four nuclear marker loci, $93.75 \%$ of the backcrossed individuals can be detected in BC 1 (Fig. $3 a$ ). In subsequent repeated backcrosses (BC 2-8), the individual detection probability for each locus decreases with the power of the backcross generation. Thus the probability of detecting the diagnostic allele in the $8^{\text {th }}$ backcross is dropping to $0.39 \%$. Using equation (5) to calculate the detectable proportion in generation ' 8 ' on basis of four diagnostic loci we get a value of $1.55 \%$ (Fig. 4 ).

Therefore, to identify introgressed individuals in higher generation backcrosses with a high reliability, more and more diagnostic markers are needed. While four diagnostic markers are sufficient for identifying $93.75 \%$ of the total backcrossed fraction in the first backcross generation (Fig. 4), nine markers are needed to achieve a similar detectable proportion of $92.5 \%$ in the second backcross generation (Fig. 5). In the third backcross generation, the detection of more than $90 \%$ is only possible with the help of at least 18 diagnostic markers.

\section{Discussion}

\section{Landscape setting and general risk scenarios}

Our case study is situated in a riparian landscape with a comprehensive population of $P$. nigra in the center and only a few $P$. nigra trees in a surrounding area of about $900 \mathrm{~km}^{2}$. In contrast to $P$. nigra, its commercial $\mathrm{F} 1$ hybrid $(P . \times$ canadensis $)$ has been planted in large amounts in rows along streets or in small plantations. This is a common spatial arrangement, which is frequently seen along European riverbanks. The other 
parental species of the hybrid, $P$. deltoides, is generally absent in the European landscape. Planted hybrid clones are known to be fertile (BRADSHAW et al., 2000; VANDEN BROECK et al., 2003b) and flowering phenology do overlap sufficiently for intertaxa fertilization (NIGGEMANN et al., 2006). In the year 2006 the flowering of both taxa did occur concurrently in our study region. Thus, intertaxa gene flow is a realistic scenario in European landscapes. Mating among and between these taxa will yield first generation backcrosses and F2 hybrids. Explicit proof of such a process in the landscape and its quantification is still difficult and prone to underestimation of the hybrid progeny. However, a detailed understanding of this process is crucial for estimating the risk of invasive gene flow from $P$. deltoides genes into $P$. nigra. This could lead to hybrid swarm formation and gene swamping (SEEHAUSEN, 2004).

A hybrid swarm may form when hybrids recurrently mate with themselves and/or are subsequently backcrossed with the native parental species (GRANT, 1981). If backcrossing only occurs in one preferred direction, the gene pool of the introgressed taxa may be swamped (HAMZEH et al., 2007). In the long term, the genes of one taxon will establish within the gene pool of the other, using the intermediate hybrids (see KRAHULCOVÁ et al., 1996).

While some studies have not provided any indications for introgressed black poplars (IMBERT and LEFÈVRE, 2003; Fossati et al., 2003; TABBEner and CotTrell, 2003; VANDEN BROECK et al., 2006), hybrid background of poplar offspring was found in other studies (AHRENS et al., 1998; SMULDERS et al., 2008; ZIEGENHAGEN et al., 2008). The studies demonstrate that in spatial proximity, $P$. nigra and $P$. $\times$ canadensis mating does occur and seedlings will establish eventually. However, the simple assessment of the presence of a hybrid background does not allow us to distinguish between different mating scenarios. Therefore, we developed a scheme for more explicit analyses of the direction and strength of intertaxa gene flow. For conservation issues and risk analysis, we may distinguish between more obvious risk and more subtle risk scenarios.

\section{Introgression of $P$. nigra seeds through pollination by $P . \times$ canadensis}

An obvious risk is presented by the fertilization of female $P$. nigra by male $P . \times$ canadensis, since this would establish a hybrid swarm (ALLENDORF et al., 2001). Our data reveal that this is a likely scenario since we found such backcrosses, not only in the seeds but also in the established juveniles. Although it is generally low, the proportion substantially increased under distorted proportions of pollen availability, as was the case in one particular tree (2043.4), which is located far outside the main $P$. nigra population and surrounded by numerous F1 hybrid males. Our results support the hypothesis of pollen competition (RAJORA, 1989), where in a mixed pollen cloud, pollen from $P$. nigra may be more successful in pollinating female black poplar than pollen from $P . \times$ canadensis. Yet, the simultaneous presence of pollen from both taxa does not completely prevent fertilization of $P$. nigra females by $P . \times$ canadensis males, as postulated by VANDEN BROECK et al. (2004). The generally low proportion of $P$. nigra $\times P$. $\times$ canadensis backcrosses may be due to a reproductive barrier acting more effectively in this than in the opposite direction. In producing the initiate F1 hybrids, strict postzygotic barriers were found to act when female $P$. nigra were crossed with male $P$. deltoides (MELCHIOR and SEITZ, 1968). However, in the case of fertile male F1 hybrids with a considerable proportion of the $P$. nigra genome, this barrier may have become weaker than in the initial crosses using just pure species (as in Pinus, see WACHOWIAK et al., 2006). Since each next generation backcross event drives the genome more and more towards $P$. nigra, a more effective introgression of $P$. deltoides genes into the gene pool of $P$. nigra is likely.

\section{Backcrossed P. $\times$ canadensis juveniles and F2 hybrid formation}

A further and more subtle risk scenario would be given by the occurrence of F2 hybrids and backcrosses of the opposite direction. These can be regarded as a reservoir for $P$. deltoides genes remaining in the landscape even after the cultivated $\mathrm{F} 1$ hybrids have disappeared. However, we found F2 progeny, and thus evidence for such a scenario, in the seedlings only. Fertility among the cultivars is therefore proven, but we cannot exclude either early viability selection against F2 seedlings or the presence of selective forces acting against F2 hybrids in the field. This mechanism is called hybrid breakdown (STEBBINS, 1958) and is a common effect of hybridization. While the F1 hybrid is viable and known to perform even better due to heterosis, the F2 hybrid and later generations often perform poorly or they are even nonviable (RIESEBERG and CARNEY, 1998). In the genus poplar it is known that species have naturally existed in sympatry for long periods but little introgression has so far been found (HEINZE and LICKL, 2002; VANDEN BROECK et al., 2005; LEXER et al., 2010), providing further evidence for the hybrid breakdown theory. In contrast, SMULDERS et al. (2008) did classify six out of 44 investigated juveniles as F2 hybrids. In our case, we may have either underestimated the proportions of F2 hybrids in the seeds or simply overlooked them in the juveniles, due to the relatively low proportion of detectable F2. In addition, the small sample size of juveniles and/or the spatial configuration of male and female $\mathrm{F} 1$ hybrids in vicinity of the regeneration site may have played a role.

Intuitively, at the first sight introgression of male $P$. nigra into female $P . \times$ canadensis does not seem of conservational relevance. F1 hybrid mother trees are heavily pollinated by $P$. nigra even if the trees (e.g. 2025.2) are located far away from the next black poplar male. In subsequent generations, this would lead to an attenuation of $P$. deltoides nuclear genes in the landscape, given that the pattern of introgression of $P$. nigra pollen continues during the next backcross generations. What is the risk of such a scenario? The purely maternally inherited chloroplast genome will remain $P$. deltoides specific. According to our data, we found individuals of the first backcross generation. In the juveniles investigated, half of the individuals with a hybrid back- 
ground originated from $P$. $\times$ canadensis mothers. Therefore, the establishment of first generation backcrosses in nature is at least possible.

Furthermore, the high proportion of $P$. nigra paternity is probably not only due to the pollen cloud composition, but also due to selective forces acting at the pre/postzygotic barrier since overall, $P$. nigra paternity exceeded $P$. $\times$ canadensis paternity by far. We therefore propose that the hypothesis of pollen competition (RAJORA, 1989) can be applied to the pollination of $P . \times$ canadensis females as well. Through such 'pollen swamping' (PETIT, 2004) of $P$. nigra into offspring of $P$. $\times$ canadensis, at first sight $P$. deltoides nuclear genes may be attenuated in the landscape but the local gene pools of both taxa remain merged. Thus, an everlasting reservoir of $P$. deltoides alleles will become established in our landscape. This type of constant introgressive gene flow therefore significantly contributes to hybrid swarm formation, as do the other more obvious risk scenarios. Apart from the purely genomic aspects, introgressed black poplar populations may additionally suffer from fitness deficit, especially as their rarity contrasts with the widely planted F1 hybrid cultivar (Ellstrand et al., 1999; MALLET, 2005). Hybrid poplar plantations mostly consist of a few clones and hence exhibit a low level of diversity. Therefore, frequent mating events between the taxa are considered to reduce the genetic diversity of the introgressed $P$. nigra populations which so far still exhibit a considerably high genetic diversity (e.g. CAGELLI and LEFÈVRE, 1995; AHRENs et al., 1998; LEFÈVRE et al., 2001).

\section{Potential and limitations of the tool}

Our scheme provides a refined tool for an explicit reconstruction of mating scenarios in the $P$. nigra $P$. $\times$ canadensis hybrid complex. With the help of the tool we also clearly defined non-detectable proportions of poplars with different hybrid background. As compared to other approaches that use a combination of markers we either enlarged the set of markers (ZIEGENHAGEN et al., 2008) or instead of using bi-allelic nuclear markers (HEINZE and LiCKL, 2002; CsEnCSICS et al., 2009) we included polymorphic nuclear microsatellite markers, which can easily be complemented for the purpose of cultivar fingerprinting and explicit parentage analyses in populations. Our system has additional advantages: it neither needs time and cost-consuming parentage analyses nor does it require the presence of HardyWeinberg equilibria (HWE) such as Bayesian clustering does. Even under given HWE, advanced Bayesian modeling may risk of falsely classifying hybrid scenarios in later generations. Although the underestimation of hybrid progeny is still more probable for some mating scenarios than for others, our diagnostic marker system was suitable for the resolution of introgressive gene flow from $P . \times$ canadensis to $P$. nigra or vice versa.

The power of our empirical study is due to the simple setting that only pure $P$. nigra and commercially produced first generation hybrids are interbreeding. Even if a low proportion of $\mathrm{BC}$ adults would have been already present in the landscape, while not analyzed, these have not really become effective since we found only a low proportion of just $4.2 \% \mathrm{BC}$ in our naturally regenerated juveniles. But this holds true only under the given setting. In this respect the projections of our scheme are illustrative for cases where hybrid swarms are developing. It enables to quantify the number of loci necessary for hybrid detection in consecutive generations. Due to the fact that many more diagnostic nuclear alleles have become available in Populus (MEIRMANs et al., 2007) it is possible to iteratively add loci to the scheme to obtain sufficient power of the system also for working in consecutive hybrid generations. A limitation is given when the number of necessarily unlinked loci will exceed the number of linkage groups. This may require genomewide analyses instead of a marker-locus approach. And finally, the specific rates of introgression will vary in space and time, due to stochastic events and local spatial settings of taxa and sexes.

For a conclusive evaluation of these invasive processes, further issues must be considered. For example, the viability and fertility of backcrosses and F2 hybrids may alter the frequencies of these scenarios. In our case we did not find any F2 hybrid within the natural regeneration. Further research on the genetic background of seedling establishment and fitness is therefore required to evaluate the consequences for the natural regeneration of $P$. nigra populations. Introgressive gene flow seems to occur regularly under field conditions but detailed mating scenarios are hard to predict. Since data of effective pollen dispersal distances in poplar are available (RATHMACHER et al., 2010), suggesting that pollen flow is most important at the regional scale, our results hint at the existence of a pre/postzygotic barrier.

\section{Conservation issues}

Our results should constitute the basis for spatial models of introgressive gene flow and should thus be useful for spatially oriented management in conservation programs. Considering spatial configuration in selecting potentially "safe" plantation sites, it would be possible to avoid or at least reduce introgressive gene flow into natural stands of P. nigra, and therefore prevent these stands from becoming hybrid swarms. Such spatial models would be extremely helpful once short rotation plantations become a common setup in the landscape as subsidiary plantations for energy crops. Because clones used for these plantations are products from crossings of native and foreign poplar species, gene flow between plantations and local $P$. nigra stands will lead to hybridization and to introgression of foreign genes into the local gene pool. Since these plantations will be commonly set up by a few clones, introgressive gene flow into native $P$. nigra populations nearby would furthermore lead to reduced genetic diversity in the offspring. Therefore, it is highly recommended to spatially separate such plantations from native $P$. nigra stands.

\section{Acknowledgements}

This research was funded by the Federal Ministry of Education and Research of the Federal Republic of Germany (BMBF, grant no. 0313285J) within the framework "Transgenic woody plant species". We would like to thank Dagmar KudERnatsch, Katharina BudDE, 
MELANIE KöHNEN and the public utility company Fritzlar for valuable help in sample and data collection. For helpful advice in the laboratory, we would like to thank Christina Mengel and SASCHA Liepelt. We would like to thank two anonymous reviewers for their valuable comments on a former version of the manuscript.

\section{References}

Ahrens, P., H. Coops, J. JAnsen and B. Vosman (1998): Molecular genetic analysis of black poplar (Populus nigra L.) along Dutch rivers. Mol Ecol 7: 11-18.

Anderson, E. C. and E. A. Thompson (2002): A modelbased method for identifying species hybrids using multilocus genetic data. Genetics 160: 1217-1229.

Allendorf, F. W., R. F. Leary, P. Spruell and J. K. WenBURG (2001): The problems with hybrids: setting conservation guidelines. Trends Ecol Evol 16: 613-622.

ARNOLD, M. L. (1997): Natural hybridization and evolution. Oxford University Press US.

BekKaoui, F., B. MANn and B. Schroeder (2003): Application of for the identification and management of hybrid poplar accessions. Agroforestry Systems 59: 53-59.

Bradshaw, H., R. Ceulemans, J. Davis and R. Stettler (2000): Emerging model systems in plant biology: Poplar (Populus) as a model forest tree. J Plant Growth Regul 19: 306-313.

CAGELli, L. and F. LeFÈvRE (1995): The conservation of Populus nigra L. and gene flow with cultivated poplars in Europe. Forest Genetics 2: 135-144.

Csencsics, D., S. Angelone, M. Paniga, P. Rotach, A. Rudow, E. Sabiote, P. Schwab, P. Wohlhauser and R. HoldEREGGER (2009): A large scale survey of Populus nigra presence and genetic introgression from nonnative poplars in Switzerland based on molecular identification. J Nat Conserv 17: 142-149.

Cervera, M., V. Storme, B. Ivens, J. Gusmao, B. H. Liu, V. Hostyn, J. Van Slycken, M. Van Montagu and W. BOERJAN (2001): Dense genetic linkage maps of three Populus species (Populus deltoides, P. nigra and P. trichocarpa) based on AFLP and microsatellite markers. Genetics 158: 787-809.

Demesure, B., N. Sodzi and R. J. Petit (1995): A set of universal primers for amplification of polymorphic noncoding regions of mitochondrial and chloroplast DNA in plants. Mol Ecol 4: 129-134.

Ellstrand, N. C., H. C. Prentice and J. F. Hancock (1999): Gene flow and introgression from domesticated plants into wild relatives. Annu Rev Ecol Syst 30: 539-563.

Elton, C. (1958): The ecology of invasions by animals and plants. Methuen, London.

Fossati, T., F. Grassi, F. Sala and S. Castiglione (2003): Molecular analysis of natural populations of Populus nigra L. intermingled with cultivated hybrids. Mol Ecol 12: 2033-2043.

Gaudet, M., V. Jorge, I. Paolucci, I. Beritognolo, G. Mugnozza and M. SABATTI (2008): Genetic linkage maps of Populus nigra L. including AFLPs, SSRs, SNPs, and sex trait. Tree Genetics \& Genomes 4: 25-36.

GRANT, V. (1981): Plant speciation. $2^{\text {nd }}$ ed. Columbia University Press, New York.

Hamzeh, M., C. Sawchyn, P. PÉRInet and S. Dayanandan (2007): Asymmetrical natural hybridization between Populus deltoides and P. balsamifera (Salicaceae). Can J Bot 85: 1227-1232.
HeINZE, B. (1998): PCR-based chloroplast DNA assays for the identification of native Populus nigra and introduced poplar hybrids in Europe. Forest Genetics 5: 31-38.

HEINZE, B. (2008): Genetic traces of cultivated hybrid poplars in native black poplar (Populus nigra) offspring in Austria. Preslia 80: 365-374.

Heinze, B. and E. LicKL (2002): Rare, but steady, introgression in Austrian black poplar as a long-term risk? In: VAN DAM, B. and S. BORDÁCS (eds): Genetic diversity in river populations of European Black Poplar - Implications for riparian eco-system management. Proceedings of an International Symposium held in Szekszárd, Csiszár Nyomda, Budapest, pp. 169-175.

IMBERT, E. and F. LEFÈVRE (2003): Dispersal and gene flow of Populus nigra (Salicaceae) along a dynamic river system. J Ecol 91: 447-456.

Jump, A. S., F. I. WOOdWARD and T. BuRKe (2003): Cirsium species show disparity in patterns of genetic variation at their range-edge, despite similar patterns of reproduction and isolation. New Phytol 160: 359-370.

Keller, S. R., M. S. Olson, S. Silim, W. Schroeder and P. TIFFIN (2010): Genomic diversity, population structure, and migration following rapid range expansion in the Balsam Poplar, Populus balsamifera. Mol Ecol 19: 1212-1226.

KelleR, S. R. and D. R. TAYLOR (2010): Genomic admixture increases fitness during a biological invasion. Journal of Evolutionary Biology 23: 1720-1731.

Khasa, D., P. Pollefeys, A. Navarro-Quezada, P. Perinet and J. Bousquet (2005): Species-specific microsatellite markers to monitor gene flow between exotic poplars and their natural relatives in eastern North America. Molecular Ecology Notes 5: 920-923.

Krahulcová, A., F. Krahulec and J. KIRSChNER (1996): Introgressive hybridization between a native and an introduced species: Viola lutea subsp. sudetica versus V. tricolor. Folia Geobot 31: 219-244.

Lefèvre, F., D. KaJba, B. Heinze, P. Rotach, S. M. G. DE VRIES and J. TUROK (2001): Black poplar: A model for gene resource conservation in forest ecosystems. Forestry Chronicle 77: 239-244.

Lefèvre, F., A. LÉGionnet, S. M. G. DE VRIES and J. TUROK (1998): Strategies for the conservation of a pioneer tree species, Populus nigra L., in Europe. Genet Sel Evol 30: 181-196.

Lexer, C., J. A. Joseph, M. van Loo, T. Barbara, B. Heinze, D. Bartha, S. Castiglione, M. F. Fay and C. A. BuERKLE (2010): Genomic admixture analysis in European Populus spp. reveals unexpected patterns of reproductive isolation and mating. Genetics 186: 699-712.

MALLET, J. (2005): Hybridization as an invasion of the genome. Trends Ecol Evol 20: 229-237.

Meirmans, P. G., M. Lamothe, P. Perinet and N. Isabel (2007): Species-specific single nucleotide polymorphism markers for detecting hybridization and introgression in poplar. Can J Bot 85: 1082-1091.

MELCHIOR, G. and F. SEITZ (1968): Interspezifische Kreuzungssterilität innerhalb der Pappelsektion Aigeiros. Silvae Genetica 17: 88-93.

Mooney, H. A. and E. E. Cleland (2001): The evolutionary impact of invasive species. Proc Natl Acad Sci USA 98: $5446-5451$.

Niggemann, M., G. Rathmacher and R. Bialozyt (2006): The risk of introgression of foreign genes in Populus spec. differences in the flowering phenology of $P$. nigra and $P . \times$ canadensis. In: HofFMeISTER, T. and M. DIEKMANN (eds): Proceedings of the GfÖ, Vol. 36, p. 91. 
Petit, R. J. (2004): Biological invasions at the gene level. Diversity \& Distributions 10: 159-165.

Pospísková, M. and I. SÁlKová (2006): Population structure and parentage analysis of black poplar along the Morava River. Can J For Res 36: 1067-1076.

PRitchard, J. K., M. Stephens and P. Donnelly (2000): Inference of population structure using multilocus genotype data. Genetics 155: 945-959.

RAJORA, O. P. (1989): Pollen competition among Populus deltoides Marsh., P. nigra L. and P. maximowiczii Henry in fertilizing $P$. deltoides ovules and siring its seed crop. Sex Plant Reprod 2: 90-96.

Rathmacher, G., M. Niggemann, M. Köhnen, B. ZiegenHAGEN and R. BIALOZYT (2010): Short-distance gene flow in Populus nigra L. accounts for small-scale spatial genetic structures: implications for in situ conservation measures. Conserv Genet 11: 1327-1338.

Rathmacher, G., M. Niggemann, H. Wypukol, K. GebHARDT, B. Ziegenhagen and R. BialozyT (2009): Allelic ladders and reference genotypes for a rigorous standardization of poplar microsatellite data. Trees 23: 573-583.

Rhymer, J. M. and D. Simberloff (1996): Extinction by hybridization and introgression. Annu Rev Ecol Syst 27: 83-109.

Richardson, D. M., P. Pys̆ek, M. RejMÁnek, M. G. BARBour, F. D. PANetTa and C. J. West (2000): Naturalization and invasion of alien plants: concepts and definitions. Diversity \& Distributions 6: 93-107.

RieseberG, L. H. and S. E. CARNEY (1998): Plant hybridization. New Phytol 140: 599-624.

van DER Schoot, J., M. PospíšKovÁ, B. Vosman and M. J. M. SMULDERS (2000): Development and characterization of microsatellite markers in black poplar (Populus nigra L.). Theor Appl Genet 101: 317-322.

SEEHAUSEN, O. (2004): Hybridization and adaptive radiation. Trends Ecol Evol 19: 198-207.

Smulders, M. J. M., R. Beringen, R. Volosyanchuk, A. VAnden Broeck, J. van Der Schoot, P. Arens and B. Vosman (2008): Natural hybridisation between Populus nigra L. and $P . \times$ canadensis Moench. Hybrid offspring competes for niches along the Rhine river in the Netherlands. Tree Genetics \& Genomes 4: 663-675.

Smulders, M. J. M., J. VAN DER Schoot, P. ARENS and B. Vosman (2001): Trinucleotide repeat microsatellite markers for black poplar (Populus nigra L.). Mol Ecol Notes 1: 188-190.

StebBins, G. L. (1958): The inviability, weakness, and sterility of interspecific hybrids. In: DEMEREC, M. (eds): Advances in genetics, Vol 9, Academic Press Inc, pp. 147-215.
Thompson, S. L., M. Lamothe, P. G. Meirmans, P. Perinet and N. IsABEL (2010): Repeated unidirectional introgression towards Populus balsamifera in contact zones of exotic and native poplars. Mol Ecol 19: 132-145.

TABBEner, H. E. and J. E. CotTrell (2003): The use of PCR based DNA markers to study the paternity of poplar seedlings. For Ecol Manage 179: 363-376.

Vanden Broeck, A., V. Storme, J. E. Cottrell, W. BoerJAN, E. VAN Bockstaele, P. QuATAERT and J. VAN SlycKEN (2004): Gene flow between cultivated poplars and native black poplar (Populus nigra L.): a case study along the river Meuse on the Dutch-Belgian border. For Ecol Manage 197: 307-310.

VAnden Broeck, A., J. Cottrell, P. Quataert, P. Breyne, V. Storme, W. BoerJan and J. V. van Slycken (2006): Paternity analysis of Populus nigra L. offspring in a Belgian plantation of native and exotic poplars. Ann For Sci 63: 783-790.

Vanden Broeck, A., K. Cox, P. Quataert, E. van BockSTAELE and J. VAN SLYCKEN (2003a): Flowering phenology of Populus nigra L., P. nigra cv. Italica and $P$. $\times$ canadensis Moench. and the potential for natural hybridisation in Belgium. Silvae Genetica 52: 280-283.

VANDEN Broeck, A., P. Quartaert, I. RoldÁN-Ruiz, E. VAN Bockstaele and J. van Slycken (2003b): Pollen competition in Populus nigra females revealed by microsatellite markers. Forest Genetics 10: 219-227.

Vanden Broeck, A., M. Villar, E. V. Bockstaele and J. VAN SLYCKEN (2005): Natural hybridization between cultivated poplars and their wild relatives: evidence and consequences for native poplar populations. Ann For Sci 62: 601-613.

Wachowiak, W., B. R. Stephan, I. Schulze, W. PrusGlowaCKI and B. ZiEgenhagen (2006): A critical evaluation of reproductive barriers between closely related species using DNA markers - a case study in Pinus. Plant Syst Evol 257: 1-8.

Ziegenhagen, B., S. Gneuss, G. Rathmacher, I. Leyer, R. Bialozyt, B. Heinze and S. Liepelt (2008): A fast and simple genetic survey reveals the spread of poplar hybrids at a natural Elbe river site. Conserv Genet 9: 373-379.

Ziegenhagen, B., P. Guillemaut and F. Scholz (1993): A procedure for mini-preparations of genomic DNA from needles of silver fir (Abies alba Mill.). Plant Mol Biol Rep 11: 117-121.

Zsuffa, L., D. Lin and P. PAYNe (1999): One-way crossing barriers in some interspecific crosses of Aigeiros and Tacamahaca poplars. For Chron 75: 833-836. 